\title{
Performance of Hybrid Anammox Reactor Using a Pile Fabric as Biomass Carier for High Nitrogen Removal Rate
}

\author{
Diansyah, G, Agustina, TE, Novia, Takekawa, M, Ma, Y, and Furukawa, K
}

\begin{abstract}
Ammonia removal from wastewater using anaerobic process called anammox which in effect will result in the removal of nitrogen is paramount. Anammox is a biological method of nitrogen removal which is considered to be efficient, cheap and environmentally friendly. This study is aimed to evaluate the feasibility of hybrid anammox reactor for removal of synthetic wastewater containing high ammonia concentration. The anammox hybrid reactor with an effective volume of $6.0 \mathrm{~L}$ was operated with two parts, combining fixed bed in the upper part and fluidized bed in the bottom part. The upper part was constructed with a porous polyester pile fabric material to effectively attach the suspended sludge. A maximum nitrogen removal rate $(\mathrm{NRR})$ of $15.3 \mathrm{~kg}-\mathrm{N} \mathrm{m}^{-3} \mathrm{~d}^{-1}$ was reached on the operation day 97 with a TN removal efficiency of $77 \%$. From the viewpoint of the biomass concentration, the fluidized bed was considerably responsible for $82 \%$ of the total nitrogen removal.
\end{abstract}

Keywords-Anammox, Hybrid reactor, Pile fabric, Nitrogen removal.

\section{Introduction}

Nitrogen is known to be one of the causes of eutrophication as a result of an abundance of ammonium in surface water when the effluent of untreated municipal wastewater is discharged into water bodies [1]. In order to reduce fixed nitrogen such as

Gusti Diansyah*

Department of Marine Science,

Sriwijaya University, Indonesia

*Corresponding author

Tuty Emilia Agustina

Department of Chemical Engineering,

Sriwijaya University, Indonesia

Novia

Department of Chemical Engineering,

Sriwijaya University, Indonesia

Masashi Takekawa

Graduate School of Science and Technology,

Kumamoto University, Japan

Ma Y

Graduate School of Science and Technology,

Kumamoto University, Japan

Furukawa Kenji

Graduate School of Science and Technology,

Kumamoto University, Japan ammonium $\left(\mathrm{NH}_{4}{ }^{+}\right)$and nitrate $\left(\mathrm{NO}_{3}{ }^{-}\right)$from wastewater, conventional wastewater treatment systems predominately apply the aerobic nitrification process followed by the anaerobic denitrification process [2]. In this system, supply of oxygen as electron acceptor for nitrification process and supply of extra carbon source for anoxic heterotrophic denitrification are fully required and result in the increasing of the operational cost.

A new process in the nitrogen cycle called anaerobic ammonium oxidation (Anammox) was discovered in the mid 1990's [3]. This process yields the dinitrogen gas from ammonium oxidation and nitrite reduction under anaerobic condition [4]. Some of the advantages of the Anammox process in comparison to conventional nitrification/denitrification include reduced oxygen demand (thus less energy input), no need for external carbon addition $\left(\mathrm{CO}_{2}\right.$ is used instead as carbon source for bacteria growth), negligible sludge production, lower space requirement and hence higher cost-effectiveness [5; 6]

In the present research, we worked with similar reactor with that of Ma et al. [7] to investigate the performance of anammox process for high nitrogen removal rate in an hybrid reactor using a pile fabric as biomass carrier.

\section{Materials and Methods}

\section{A. Seed anammox sludge}

The anammox sludge which contains KSU-1 and KU-2 strains [8] was used for inoculation. The enriched anammox sludge was originated from an up-flow fixed bed reactor fed with synthetic wastewater [8].

\section{B. Reactor and experimental setup}

The schematic overview of the hybrid anammox reactor is depicted in Figure 1. The anammox hybrid reactor with an effective volume of $6.0 \mathrm{~L}$ was designed with two parts, combining fixed bed in the upper part and fluidized bed in the bottom part. The upper part was constructed with a porous polyester pile fabric material (Ohyapile, Japan) to effectively attach the suspended sludge. In the fluidized bed, a mechanical stirrer (Z-2200. Tokyo Rikakikai, Japan) was installed to increase mass transfer between biomass and wastewater and at the same time to release the dinitrogen gas from the sludge. 
Proc. of The Third Intl. Conf. On Advances in Applied Science and Environmental Technology - ASET 2015 Copyright $\odot$ Institute of Research Engineers and Doctors, USA .All rights reserved.

ISBN: 978-1-63248-084-2 doi: 10.15224/ 978-1-63248-084-2-93

The hybrid anammox reactor was operated at $32^{\circ} \mathrm{C}$ controlled thermostatically with a thermostated jacket. A pH controller was introduced to preserve the $\mathrm{pH}$ at around 7.0-7.4 by adding the $\mathrm{HCl} 0.1 \mathrm{M}$. To keep the reactor in anaerobic condition, the dissolved oxygen (DO) concentration in the influent was consistently maintained below $1.0 \mathrm{mg} / \mathrm{L}$ in which the influent was flushed with nitrogen gas. Besides, the reactor was enclosed with a black vinyl sheet to prevent the light interference that possibly reduces $30-50 \%$ of ammonium removal rate [4]. The feeding solution in the influent tank was filled to the reactor from the bottom in an up-flow mode by a peristaltic pump (RP-2000, Rikakikai Japan).

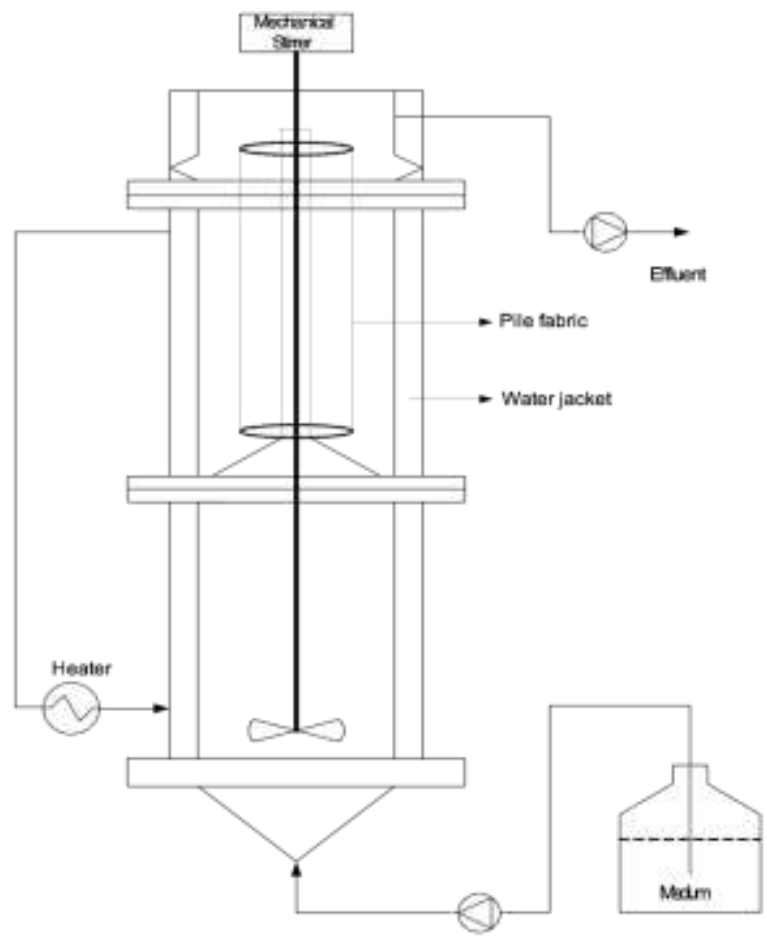

Figure 1. Schematic of hybrid anammox reactor used for continuous treatment.

\section{Feeding Media}

In this study, synthetic wastewater which contains $\mathrm{NH}_{4}{ }^{+}-\mathrm{N}$ and $\mathrm{NO}_{2}^{-}-\mathrm{N}$ was made and continuously filled into the hybrid anammox reactor. $\left(\mathrm{NH}_{4}\right)_{2} \mathrm{SO}_{4}$ and $\mathrm{NaNO}_{2}$ were used as the ammonium and nitrite sources with molar ratio 1.0-1.2. During the experiments, $150-350 \mathrm{mg} / \mathrm{L}$ of $\mathrm{NH}_{4}{ }^{+} \mathrm{N}$ and $150-$ $350 \mathrm{NO}_{2}^{-}-\mathrm{N}$ was used as influent concentration of synthetic medium. In addition, the other components consisting of $\mathrm{KHCO}_{3}$ 125-500 mg/L, $\mathrm{KH}_{2} \mathrm{PO}_{4} 54 \mathrm{mg} / \mathrm{L}, \mathrm{FeSO}_{4} .7 \mathrm{H}_{2} \mathrm{O} 9$ $\mathrm{mg} / \mathrm{L}$ and EDTA were also added to the synthetic medium.

\section{Analytical method}

Ammonium nitrogen $\left(\mathrm{NH}_{4}{ }^{+}-\mathrm{N}\right)$ was quantified based on the indophenol reaction with ortho-phenylphenol (OPP). Nitrite nitrogen $\left(\mathrm{NO}_{2}^{-}-\mathrm{N}\right)$ was determined with the colorimetric method (APHA, 1995) and nitrate nitrogen $\left(\mathrm{NO}_{3}{ }^{-} \mathrm{N}\right)$ with the ultraviolet spectrophotometric screening method (APHA,
1995). $\mathrm{pH}$ and $\mathrm{DO}$ was measured using a $\mathrm{pH}$ meter (F55, Horiba Ltd, Japan) and a DO meter (OM-51, Horiba Ltd, Japan). For MLSS and MLVSS determination, the centrifuged sludge sample was dried at $105^{\circ} \mathrm{C}$ and $550^{\circ} \mathrm{C}$ respectively.

\section{Results}

\section{a. Nitrogen removal}

The hybrid anammox reactor was operated during 111 days. The reactor was continuously fed with ammonium and nitrite with a ratio 1:1.1. The time course of influent and effluent nitrogen concentrations is shown in Figure 2. As can be observed from this figure, during the operation, the influent total nitrogen concentration was increasing up to $685 \mathrm{mg} / \mathrm{L}$ (with $340 \mathrm{mg} / \mathrm{L} \quad \mathrm{NH}_{4}{ }^{+}-\mathrm{N}$ and $340 \quad \mathrm{mg} / \mathrm{L} \quad \mathrm{NO}_{2}{ }^{-} \mathrm{N}$ approximately) in the end of experiment. Meanwhile, hydraulic retention time (HRT) was decreasing from 8 hours in the beginning to 0.8 hours in the end of operation (Figure $3)$.

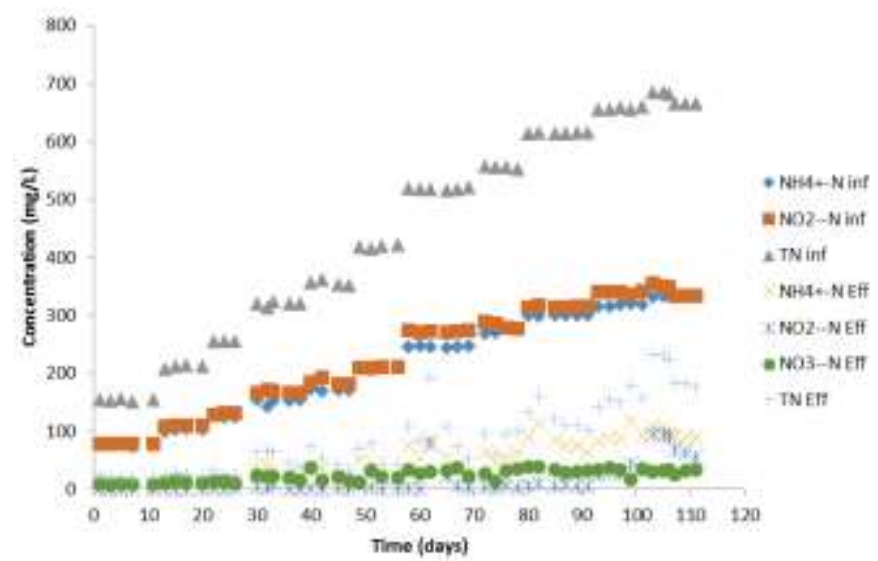

Figure 2. Evolution of the nitrogen concentration in the influent the effluent along the operational period.

The reactor was started up with an influent total nitrogen (TN) concentration of $150 \mathrm{mg} / \mathrm{L}$ resulting a feed loading rate of 0.5 $\mathrm{kg}-\mathrm{N} \mathrm{m}^{-3} \mathrm{~d}^{-1}$. In Ma et al. (2011), an internal circulation and a continuous stirring at $30 \mathrm{rpm}$ were installed and performed during days 1-39 resulting a rapidly increasing of the nitrogen loading rate (NLR) from 0.35 to $1.2 \mathrm{~kg}-\mathrm{N} \mathrm{m} \mathrm{d}^{-1}$. This indicates that applying the internal circulation during start up period is important to increase biomass retention. However, in our study, during start-up period, increasing the influent TN concentration and decreasing HRT increased the NLR during days 1-26. The NLR during this period was increased from 0.5 to $2.0 \mathrm{~kg}-\mathrm{N} \mathrm{m}^{-3} \mathrm{~d}^{-1}$ with maximum removal efficiency was 90 $\%$ indicating a better adaptation of anammox bacteria than earlier phase. 
Proc. of The Third Intl. Conf. On Advances in Applied Science and Environmental Technology - ASET 2015 Copyright $($ Institute of Research Engineers and Doctors, USA .All rights reserved.

ISBN: 978-1-63248-084-2 doi: 10.15224/ 978-1-63248-084-2-93

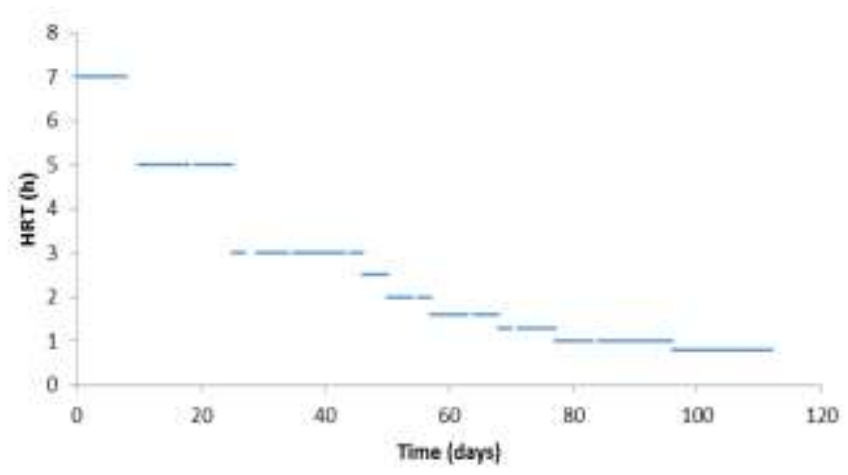

Figure 3. Time course of HRT during reactor operation.

As can be seen in Figure 4, as the capacity of nitrogen removal of the system going up after a successful start-up, both the ammonium and nitrite concentrations in the influent flows were gradually increased from 100 to $350 \mathrm{mg} / \mathrm{L}$. Besides, from days 22-96, the HRT was reduced from 5 to 0.8 hours. Consequently, the NLR increased from 1.2 to $20.5 \mathrm{~kg}-\mathrm{N} \mathrm{m}{ }^{-3} \mathrm{~d}^{-}$ 1. During this period, a relatively high TN removal efficiency was obtained with the average was $81.5 \pm 6 \%$. This value was lower compared with the maximum nitrogen removal based on anammox stoichiometry due to $\mathrm{NO}_{2}-\mathrm{N}$ limitation. In addition, a maximum nitrogen removal rate (NRR) of $15.3 \mathrm{~kg}-\mathrm{N} \mathrm{m}^{-3} \mathrm{~d}^{-1}$ was reached on the operation day 97 with a TN removal efficiency of $77 \%$.

At the end of operation, the total biomass concentration in fluidized bed (lower part) and on the polyester pile fabric carrier in the upper part reached $19.4 \mathrm{~g}-\mathrm{VSS} / \mathrm{L}$. A $15.9 \mathrm{~g}-$ VSS/L of anammox sludge was measured in the fluidized part, while the anammox biomasss concentration attached on the polyester pile fabric carrier was $3.5 \mathrm{~g}-\mathrm{VSS} / \mathrm{L}$. This showed, from the viewpoint of the biomass concentration, that the fluidized bed was considerably responsible for $82 \%$ of the total nitrogen removal.

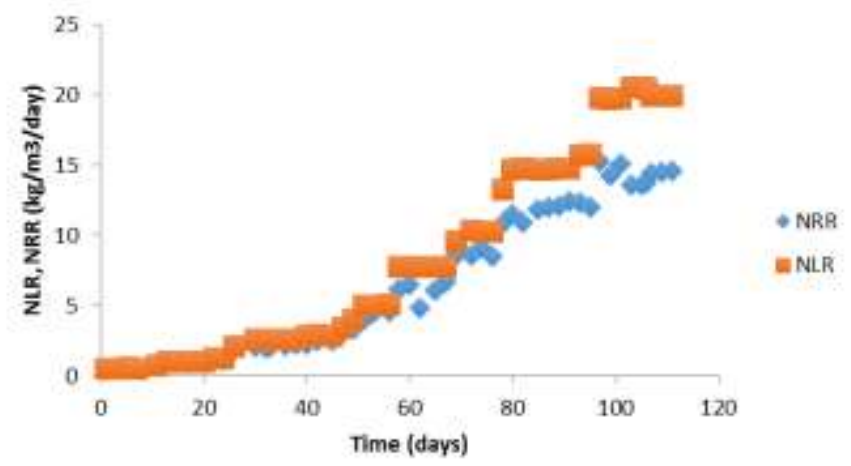

Figure 4. Time course of total NLR, NRR and nitrogen removal efficiency $(\diamond$ : NRR; $\square:$ NLR)

\section{IV.Discussion}

In the present study, the hybrid reactor was successfully applied to perform high nitrogen loading rate. The combination between fixed and fluidized beds in this reactor was employed to increase conversion capacity of the reactor. In the upper part, the fixed bed using a porous polyester pile biomass carrier was installed to effectively retain the suspended biomass and to reduce the washout. Additionally, the fluidized bed was mechanically stirred to increase the mass transport between anammox sludge and wastewater. It is also confirmed by Mulder et al. [9] that factors including biological conversion capacity, mass transport and biomass concentration are crucial in order to reach high conversion capacity of a bioreactor.

The NRR treated in this study are comparable to those previously obtained by other studies. Sliekers et al. (2003) reported a maximum NRR of $8.9 \mathrm{~kg}-\mathrm{N} \mathrm{m}^{-3} \mathrm{~d}^{-1}$ was reached using a gas-lift anammox reactor. Besides, a study from Quan et al. [10] succeeded to obtain the NRR of $8.2 \mathrm{~kg}-N ~ m^{-3} \mathrm{~d}^{-1}$. In this study, the polyvinyl alcohol (PVA) gel was used as biomass carrier entrapped anammox sludge in a stirred tank reactor (STR). Moreover, values of NRR higher than this study were referred by Tsushima et al. [11] and Ma et al. (2011) of $26.0 \mathrm{~kg}^{-\mathrm{N} \mathrm{m}} \mathrm{m}^{-3} \mathrm{~d}^{-1}$ in an up-flow fixed bed glass biofilm column reactor and of $20.7 \mathrm{~kg}-\mathrm{N} \mathrm{m}^{-3} \mathrm{~d}^{-1}$ in a hybrid anamox reactor. The maximum NRR of $20.7 \mathrm{~kg}-\mathrm{N} \mathrm{m} \mathrm{m}^{-3}$ from $\mathrm{Ma}$ et al. [7] was reached in a longer reactor operation on day 333 compared with our study on day 156. Additionally, the porous polyester non-woven fabric used by Ma et al. [7] as biomass carrier could catch more effective the suspended sludge and has a higher surface area than the porous polyester pile fabric used in our study.

\section{Acknowledgment}

The authors are grateful to Professor Kenji Furukawa and Furukawa Laboratory for providing the research.

\section{References}

1. Yang, P., M. Wendisch, L. Bi, G. Kattawar, M. Mishchenko, and Y. Hu, 2011: Dependence of extinction cross-section on incident polarization state and particle orientation.J. Quant. Spectrosc. Radiat. Transfer, 112, 2035-2039.

2. Kartal, B., Juenen, J.G., \& van Loosdrecht. (2010). Sewage Treatment with Anammox. Science. 328,702-703.

3. Mulder, A., van de Graaf, A.A., Robertson, L.A., Kuenen, J.G. (1995). Anaerobic ammonium oxidation discovered in a denitrifying fluidized bed reactor, FEMS. Microbiology Ecology, 16, 177-184

4. Van de Graaf A.A., Mulder A., De Bruijn P., Jetten M.S.M., Robertson L.A. \& Kuenen J.G. (1995). Anaerobic oxidation of ammonium is a biologically mediated process. Applied Environmental Micorobiology, 61, 1246-1251.

5. Fux, C \& Siegrist, H. (2004). Nitrogen removal from sludge digester liquids by nitri-fication/denitrifiation or partial nitritation/anammox: environmental and economical considerations. Water Science and Technology, 50 (10), 19-26. 
6. Kampschreur M J, Van Der Star W R L, Wielders H A, Mulder J W, Jetten M S M, Van Loosdrecht M C M, 2008. Dynamics of nitric oxide and nitrous oxide emission during full-scale reject water treatment. Water research, 42 (3): 812-826.

7. Ma, Y., Hira, D., Li, Z., Chen, C., \& Furukawa, K. (2011). Nitrogen removal performance of a hybrid anammox reactor, Bioresource Technology, 102 (12), 6650-6656.

8. Furukawa, K., Joseph DR., Norihara Y., \& Hayato, H. (2003) Mass cultivation of anaerobic ammoniumoxidizing sludge using a novel nonwoven biomass carrier. Journal Chemical Engineering, 36:1163-1169.

9. Mulder, R., Vereijken, T.L.F.M., Frijters, C.T.M.J., \&. Vellinga, S.H.J. (2007). Future perspectives in bioreactor development. Water Science and Technology, 44 (8), 27.

10. Quan,, L.M., Liem, T.T, Khanh, D.P., \& Furukawa, K. (2010). High ammonium wastewater treatment of stirred tank anammox reactor using polyvinyl alcohol gel as biomass carrier. Water Treatment Biology, 46(2), 109117.

11. Tsushima, I., Ogasawara, Y., Kindaichi, T., \& Okabe, S. (2007). Development of high-rate anaerobic ammoniumoxidizing (anammox) biofilm reactors. Water Resource. 41, 1623-1634.

12. M. Young, The Technical Writer's Handbook. Mill Valley, CA: University Science, 1989. 